\title{
PEMANFAATAN KULIT UBI KAYU FERMENTASI DENGAN METODE TAKAKURA DALAM PAKAN TERHADAP PERTUMBUHAN KELINCI NEW ZEALAND WHITE JANTAN LEPAS SAPIH
}

\author{
(Utilization of Fermented Cassava Peel with Takakura Method in Feed on Growth of Post \\ Weaning New Zealand White Rabbit)
}

\author{
Edi Sahputra Gurusinga ${ }^{1}$, Hasnudi ${ }^{2}$ Dan Hamdan $^{2}$
}

1. Mahasiswa Program Studi Peternakan Fakultas Pertanian Universitas Sumatera Utara

2. Staf Pengajar Program Studi Peternakan Fakultas Pertanian Universitas Sumatera Utara

\begin{abstract}
Fermented cassava peel with takakura method can increase the protein content of feed for improving the quality of feed. This study aims to determine the effect of fermented cassava peel fermented with takakura method in feed on the growth of weaning New Zealand white rabbit. The experiment was conducted in the Laboratory of Animal Biology, Faculty of Agriculture, University of Sumatera Utara. The research carried out for 2 months started from September to November 2012. The research design was used in this study was completely randomized design (CRD) with 4 treatments and 5 replications. Treatments consist of P0 (0\% fermented cassava peel), P1(10\% fermented cassava peel), P2(20\% fermented cassava peel) and P3(30\% fermented cassava peel). The results showed that administration of a variety of fermented cassava peel levels of takakura method were significantly different $(P<0.01)$ on consumption, body weight gain, and feed efficiency. It is concluded that fermented cassava peel can't be used as feed of New Zealand White Rabbit.
\end{abstract}

Keywords: Cassava peel, fermented, takakura method, rabbit, growth.

\begin{abstract}
ABSTRAK
Kulit ubi fermentasi dengan metode takakura dapat meningkatkan kandungan protein pakan yang berimplikasi pada peningkatan kualitas pakan. Penelitian ini bertujuan untuk mengetahui pengaruh pemberian kulit ubi kayufermentasidengan metode takakura dalam pakan terhadap pertumbuhan kelinci New Zealand White jantan lepas sapih Penelitian dilaksanakan di Laboratorium Biologi Ternak, Fakultas Pertanian Universitas Sumatera Utara, Medan. Penelitian dilaksanakan selama 2 bulan dimulai bulan September sampai November 2012. Rancangan penelitian yang digunakan dalam penelitian ini adalah rancangan acak lengkap (RAL) dengan 4 perlakuan dan 5 ulangan. Perlakuan terdiri atas $\mathrm{P}_{0}\left(0 \%\right.$ kulit ubi fermentasi); $\mathrm{P}_{1}(10 \%$ kulit ubi fermentasi); $\mathrm{P}_{2}\left(20 \%\right.$ kulit ubi fermentasi) dan $\mathrm{P}_{3}(30 \%$ kulit ubi fermentasi). Hasil penelitian menunjukkan bahwa pemberian berbagai level kulit ubi fermentasi dengan metode takakurasangat berbeda nyata $(\mathrm{P}<0,01)$ terhadapkonsumsi,pertambahan bobot badan dan efisiensi pakan.Dapat disimpulkan bahwa kulit ubi yang telah difermentasi tidak dapat digunakan sebagai pakan kelinci New Zealand White.
\end{abstract}

Kata kunci: Kulit ubi, fermentasi, metode takakura, kelinci, pertumbuhan. 


\section{PENDAHULUAN}

Jumlah penduduk Indonesia terus saja bertambah, mengakibatkan kebutuhan akanpermintaan pangan juga terus meningkat, terutama yang berasal dari hewani seperti daging, telur dan susu, tetapi dalam usaha pemenuhannya tidak sebanding besarnya, akibatnya banyak permintaan yang tidak terpenuhi dengan baik. Konsumsi protein hewani kerap kali dijadikan sebagai parameter dari kualitas sumber daya manusiasuatu bangsa.

Kelinci merupakan salah satu komoditas ternak penghasil daging yang memiliki potensi besar untuk dikembangkan karena memiliki sifat-sifat dan kemampuan yang menguntungkan yaitu kemampuannya untuk tumbuh dan berkembang biak yang cepat serta kadar lemak dan kolestrol dalam daging kelinci relatif lebih rendah dibandingkan ternakternak lain.Seekor kelinci menghasilkan daging $50-60 \%$ dari berat hidupnya. Daging kelinci mengandung lemak dan kolestrol jauh lebih rendah, tetapi kandungan proteinnya lebih tinggi (Masanto dan Agus, 2010).

Salah satu faktor yang mempengaruhi keberhasilan dalam pengelolaan ternak adalah faktor makanan (Tillman, 1987), dimana makanan ini berasal dari rumput potong, padang pengembalaan dan hasil liputan pertanian dan perkebunan. Faktor makanan ini juga bergantung terhadap faktor iklim, karena pada masa musim hujan makan melimpah dan waktu musim kemarau kekurangan makan, dan untuk mengatasi hal ini perlu dilakukan pengawetan pakan dan pemanfaatan sisa hasil pertanian dan perkebunan.Hasil samping pertanian dan perkebunan merupakanbahan pakan yang berpotensi untuk dimanfaatkan karena jumlahnya yang melimpah, harga murah dan nilai gizinya baik.

Pengembangan penggunaan limbah yang berasal dari agoindustri dan bahan pakan non konvensional sangat penting dilakukan (Devendra, 1987).Salah satu bahan pakan alternatif yang dapat digunakan sebagai bahan pakan untuk ternak adalah kulit ubi kayu. Kulit ubi kayu yang diperoleh dari produk tanaman ubi kayu merupakan limbah industri yang menggunakan bahan dasar ubi kayu. Pada umumnya dalam proses industri tersebut kulit ubi kayu ini dibuang sebagai limbah dan semakin luas areal tanaman ubi kayu diharapkan produksi ubi kayu semakin tinggi sehingga semakin tinggi pula limbah kulit ubi kayu. Setiap kilogram ubi kayu dapat menghasilkan 15-20\% kulit ubi (Nurhayani dkk, 2000).

Kulit ubi memiliki kandungan nutrisi yang cukup baik, tetapi tetap perlu ada usaha untuk menaikkan nilai nutrisi yang dikandung kulit ubi agar dapat memenuhi nutrisi yang dibutuhkan oleh ternak kelinci.Salah satu usaha yang dapat dilakukan untuk menaikkan nilai nutrisinya yaitu dengan fermentasi (Suyanto, 2011). 
Fermentasi adalah proses penguraian unsur-unsur kelompok organik terutama karbohidrat untuk menghasilkan energi melalui reaksi enzim yang dilakukan oleh mikroorganisme. Proses fermentasi dapat dikatakan sebagai proses protein enrichment yang berarti proses pengayaan bahan protein dengan menggunakan mikroorganisme tertentu. Pada saat ini teknologi fermentasi yang sangat sederhana serta biayanya murah adalah fermentasi dengan metode takakura yaitudengan menggunakan mikroorganisme Lactobacillus sp, Rhizopus sp, dan Saccharomyces sp, karena fermentasi ini menggunakan mikroorganisme yang mudah didapat sehingga dapaat menghemat biaya dan mudah dalam penerapannya.

Berdasarkan uraian di atas maka penulis tertarik untuk mengetahui sejauh mana pengaruh pemberian pelet sebagai pakan kelinci berbahan tepung kulit ubi yang difermentasi denganmetode takakura dalam pakan terhadap pertumbuhan kelinci New Zealand White jantan lepas sapih.

\section{BAHAN DAN METODE PENELITIAN}

\section{Lokasi dan Waktu Penelitian}

Penelitian dilaksanakan di Laboratorium Biologi Ternak Fakultas Pertanian Universitas Sumatera Utara. Penelitian dilaksanakan selama 8 minggu dimulai bulan September sampai November 2012.

\section{Bahan dan Alat Penelitian}

Bahan yang digunakan dalam penelitian ini adalah dua puluh ekor ternak kelinci New Zealand White jantan lepas sapih dengan bobot $683,7 \pm 21,2$ gram sebagai objek yang akan diteliti, kulit ubi, dedak padi, bungkil inti sawit, tepung jagung, bungkil kedelai, garam, molases dan mineral mix sebagai bahan pakan. Air tebu, ragi tempe, ragi tape, youghurt dan starbio sebagai bahan fermentator pembuatan inoculan cair serta obat-obatan seperti obat cacing (Kalbazen), Vitamin B-Kompleks dan air minum.

Alat yang digunakan yaitu kandang individual dua puluh unit dengan ukuran 50x50x50 cm,tempat pakan dan tempat minum, timbangan untuk menimbang bobot hidup berkapasitas $10 \mathrm{Kg}$ dengan kepekaan $10 \mathrm{~g}$ dan timbangan berkapasitas $5 \mathrm{Kg}$ dengan kepekaan 5 g untuk menimbang pakan, alat kebersihan (ember, sapu lidi, beko, sekop), alat tulis, kalkulator dan alat penerangan, mesin penggiling (grinder), terpal plastik untuk menjemur bahan pakan, pencatat data selama penelitian, kereta sorong sebagai alat pengangkut bahan 
pakan dan lampu sebagai alat untuk penerang kandang, pencetak peletdan termometer untuk mengetahui suhu saat fermentasi dan suhu kandang.

Tabel 1. Kandungan nutrisi bahan pakan

\begin{tabular}{lcccc}
\hline & \multicolumn{4}{c}{ KOMPOSISI BAHAN PAKAN } \\
\cline { 2 - 5 } BAHAN & PK(\%) & EM (kkal) & SK(\%) & LK(\%) \\
\hline T.jagung & $8.6^{\mathrm{a}}$ & $3370^{\mathrm{a}}$ & $2^{\mathrm{a}}$ & $3.9^{\mathrm{a}}$ \\
BIS & $14.2^{\mathrm{a}}$ & $2087^{\mathrm{a}}$ & $21^{\mathrm{a}}$ & $9.5^{\mathrm{a}}$ \\
B.kedelai & $45^{\mathrm{a}}$ & $2240^{\mathrm{a}}$ & $6^{\mathrm{a}}$ & $0.9^{\mathrm{a}}$ \\
Dedak & $11.3^{\mathrm{a}}$ & $1630^{\mathrm{a}}$ & $12^{\mathrm{a}}$ & $13^{\mathrm{a}}$ \\
Garam & & & \\
Mineral mix & & & \\
Kulit ubi fermentasi & $7^{\mathrm{b}}$ & $2551^{\mathrm{b}}$ & $16.9^{\mathrm{b}}$ & $4.12^{\mathrm{b}}$ \\
Molasses & $5^{\mathrm{a}}$ & $2330^{\mathrm{a}}$ & $8.5^{\mathrm{a}}$ & $0.08^{\mathrm{a}}$ \\
\hline Sumber : a = Laboratorium Ilmu Makanan Ternak Departemen Peternakan FP USU (2005). \\
\multicolumn{2}{c}{$\mathrm{b}=$ Laboratorium Nutrisi Loka Penelitian Kambing Sei Putih (2012). }
\end{tabular}

Komposisi susunan ransum pada pakan kerbau murrah selama penelitian tersaji pada Tabel 2.

Tabel 2. Komposisi susunan ransum

\begin{tabular}{lcccc}
\hline & \multicolumn{4}{c}{ Jumlah Bahan Pakan } \\
\cline { 2 - 5 } \multicolumn{1}{c}{ BAHAN } & P0 & P1 & P2 & P3 \\
\hline T.jagung & 40 & 35 & 32 & 27 \\
BIS & 20 & 15 & 10 & 8 \\
B.kedelai & 20 & 20 & 20 & 21 \\
Dedak & 6 & 6 & 8 & 5 \\
Garam & 2 & 2 & 2 & 2 \\
Mineral mix & 2 & 2 & 2 & 2 \\
Kulit ubi & & 10 & 20 & 30 \\
Molasses & 10 & 10 & 6 & 5 \\
\hline Total & 100 & 100 & 100 & 100 \\
\hline Nutrisi & & & & \\
\hline \multicolumn{1}{c}{ PK } & 16 & 16 & 16 & 16 \\
\multicolumn{1}{c}{ EM } & 2,544 & 2,526 & 2,516 & 2,511 \\
\multicolumn{1}{c}{ SK } & 8 & 8 & 9 & 10 \\
\hline \multicolumn{1}{c}{ LK } & 4 & 4 & 4 & 4 \\
\hline
\end{tabular}

\section{Pembuatan Inokulan Cair}

Dimasukkan air sumur sebanyak 10 liter ke dalam galon lalu dimasukkan air tebu sebanyak 1,5 liter lalu dimasukkan ragi tape dan ragi tempe masing-masing 60 gr serta youghurt 2 sendok makan kemudian diaduk bahan sampai merata lalu ditutup dengan plastik 
dan dibiarkan selama tiga hari, apabila plastik penutup galon telah kembung berarti mikroba didalam galon telah aktif dan inokulan cair siap untuk digunakan.

\section{Pembuatan Kulit Ubi Fermentasi}

Kulitubi dicampur dengan dedak padi sebanyak 15\% dari berat kulit ubi, campuran kulit ubi dengan dedak padi disiram dengan inokulan cair secara merata dengan perbandingan antara inokulan cair dan kulit ubi adalah 1 galon : $250 \mathrm{~kg}$. Kulit daging buah kopi ditutup dengan selimut sabut kelapa lalu dibolak balik dan diukur suhunya setiap hari, setelah 5 harikulit daging buah kopi fermentasi di bongkar dan di angin-anginkanlalu digrindersiap digunakan sebagai bahan pakan. Kandungan nutrisi bahan pakan tersaji pada tabel 1 .

\section{Metode Penelitian}

Adapun metode penelitian yang digunakan adalah experimental dengan rancangan acak lengkap (RAL) dengan 4 perlakuan 5 ulangan. Perlakuan yang diteliti adalah:

$\mathrm{P} 0=$ Kulit ubi fermentasi $0 \%+$ rumput lapangan

$\mathrm{P} 1=$ Kulit ubi fermentasi $10 \%+$ rumput lapangan

P2 = Kulit ubi fermentasi 20\% + rumput lapangan

P3 = Kulit ubi fermentasi 30\% + rumput lapangan

Menurut Hanafiah (2003), model matematika percobaan yang digunakan adalah:

$$
\mathbf{Y i j}=\boldsymbol{\mu}+\gamma \mathbf{i}+\mathbf{\varepsilon i \mathbf { j }}
$$

Keterangan:

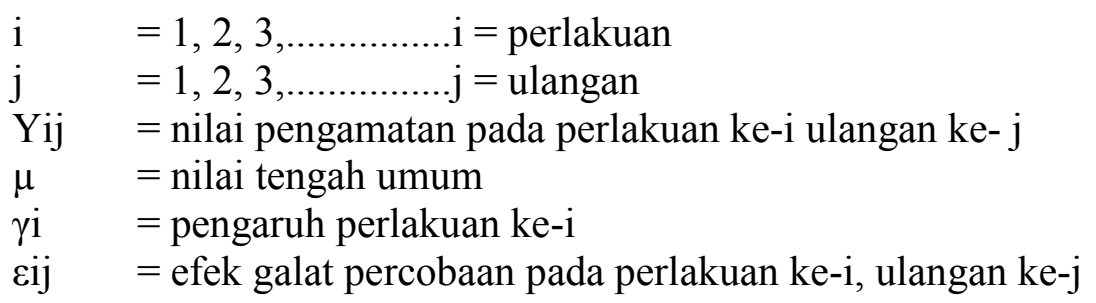

\section{Parameter Penelitian}

1. KonsumsiPakan

Konsumsi pakan diperoleh dengan menghitung selisih jumlah pakan yang diberikan dengan sisa pakan setiap harinya dan dinyatakan dengan gram per ekor per hari. Konsumsi Pakan $=$ Pakan yang diberikan $($ dalam \% BK) - Pakan yang sisa $($ dalam \% $\mathrm{BK})$. 
2. Pertambahan Bobot Badan Harian $(\mathrm{PBBH})$

Pertambahan bobot badan dihitung dengan cara membagi selisih bobot badan (bobot akhir - bobot awal) dengan lama hari penimbangan. Dilakukan selama satu minggu sekali, dinyatakan dengan gram per ekor per hari.

3. Konversi pakan

PBBH $=\underline{\text { bobot akhir }- \text { bobot awal (g/ekor) }}$

$$
\text { lama pemeliharaan (hari }
$$

Konversi pakan dihitung dengan cara membagi angka rata - rata konsumsi bahan kering per ekor per hari dengan angka rata - rata produksi pertambahan bobot badan per ekor per hari.

Konversi Pakan $=$ pakan yang dikonsumsi $(\mathrm{g} / \mathrm{hari})$

PBBH (g/hari)

\section{HASIL DAN PEMBAHASAN}

\section{Rekapitulasi Hasil Penelitian}

Rekapitulasi hasil penelitian pemanfaatan kulit ubi kayu fermentasi dengan metode takakura dalam pakan terhadap pertumbuhan kelinci New Zealand White jantan lepas sapih disajikan pada Tabel 3.

Tabel 3. Rekapitulasi hasil penelitian

\begin{tabular}{ccrc}
\hline Perlakuan & Konsumsi Ransum & Pertambahan Bobot Badan & Konversi Ransum \\
\hline P0 & $105,92^{\mathrm{c}}$ & $28,69^{\mathrm{d}}$ & $3,69^{\mathrm{a}}$ \\
P1 & $98,82^{\mathrm{b}}$ & $26,41^{\mathrm{c}}$ & $3,74^{\mathrm{ab}}$ \\
P2 & $96,36^{\mathrm{ab}}$ & $24,95^{\mathrm{b}}$ & $3,86^{\mathrm{b}}$ \\
P3 & $93,37^{\mathrm{a}}$ & $23,16^{\mathrm{a}}$ & $4,03^{\mathrm{c}}$ \\
\hline Keterangan & :Notasi huruf yang berbeda & pada kolom ratan menunjukkan berbeda sangat nyata \\
& $(\mathrm{P}<0,01)$ & &
\end{tabular}

\section{Konsumsi pakan}

Konsumsi pakan dihitung setiap hari berdasarkan selisih antara jumlah pakan yang diberikan dengan jumlah sisa pakan.Pakan yang diberikan selama penelitian ini adalah pakan hasil formulasi yang disesuaikan dengan perlakuan, pakan diberikan secara berkala dan air minum diberikan secara ad-libitum.

Tabel 3menunjukkan rata-rata konsumsi pakan kelinci (ekor/hari) dari masing-masing perlakuan selama penelitian adalah $\mathrm{P} 0=105,92, \quad \mathrm{P} 1=98,82, \mathrm{P} 2=96,36$ dan $\mathrm{P} 3=93,37$. Konsumsi pakan tertinggi secara kuantitatif dicapai pada perlakuan P0 (kulit ubi fermentasi 
0\% + rumput lapangan) dan yang terendah pada perlakuan P3 (kulit ubi fermentasi 30\% + rumput lapangan). Berdasarkan hasil analisis ragam dapat diketahui bahwa penggunaan kulit ubi kayu fermentasi dalam pakan memberikan pengaruh berbeda sangat nyata $(\mathrm{P}<0,01)$ terhadap konsumsi pakan.

Perbedaan antar perlakuan maka dilakukan dengan uji Tukey.Dari hasil uji Tukey didapat rataan konsumsi pakan pada perlakuan P0 memberikan nilai rataan yang berbeda nyata terhadap perlakuan P1, P2, dan P3.Sedangkan perlakuan P1 memberikan nilai rataan yang tidak berbeda nyata terhaadah perlakuan P2 tetapi memberikan nilai rataan yang berbeda nyata terhadap perlakuan P3 dan perlakuan P2 memberikan nilai rataan yang tidak berbeda nyata terhadap perlakuan P3.Konsumsi bahan kering pakan cenderung menurun dan lebih rendah dari pada perlakuan P0 (kulit ubi fermentasi 0\% + rumput lapangan).

Tabel 3 diatas menunjukkan bahwa rataan umum konsumsi pakan adalah sebesar 98,62 gram/ekor/hari. Angka tersebut lebih rendah daripada angka rata-rata konsumsi pakan yang diharapkan pada pemeliharaan kelinci menurut Herman (2000), yang menyatakan bahwa pemenuhan pakan kelinci dihitung berdasarkan konsumsi bahan kering.Kebutuhan bahan kering menurut NRC (1977), yaitu untuk hidup pokok 3-4\% dari bobot badan dan untuk pertumbuhan normal 5-8\% dari bobot badan. Berat rataan kelinci yaitu 2068,4 gram, maka berdasarkan data NRC kebutuhan bahan kering untuk pertumbuhan yaitu 5-8\% dari berat badan kelinci yaitu sekitar 103,42-165,47 gram/ekor/hari. Hal ini mungkin disebabkan karena tingkat palatabilitas terhadap ransum rendah dan perbedaan bobot badan kelinci. Hal ini sesuai dengan pernyataan Piliang (2000) yang menyatakan bahwa konsumsi ransum dipengaruhi beberapa faktor diantaranya adalah palatabilitas ransum, bentuk fisik ransum, bobot badan, jenis kelamin, temperatur lingkungan, keseimbangan hormonal dan fase pertumbuhan.

\section{Pertambahan Bobot Badan}

Pertambahan bobot badan dihitung setiapminggunya berdasarkan selisih antara penimbangan bobot badan akhir dengan penimbangan bobot badan awal per satuan waktu dalam satuan gram/ekor/hari. Tabel 3menunjukkan rata-rata pertambahan bobot badan kelinci (gram/ekor/hari) dari masing-masing perlakuan selama penelitian adalah $\mathrm{P} 0=28,69$, $\mathrm{P} 1=26,41, \mathrm{P} 2=24,95$ dan $\mathrm{P} 3=23,16$. Pertambahan bobot badan kelinci tertinggi secara kuantitatif dicapai pada perlakuan P0 (kulit ubi fermentasi 0\% + rumput lapangan) dan yang terendah pada perlakuan P3 (kulit ubi fermentasi 30\% + rumput lapangan). Berdasarkan hasil 
analisis ragam dapat diketahui bahwa penggunaan kulit ubi kayu fermentasi dalam pakan memberikan pengaruh berbeda sangat nyata $(\mathrm{P}<0,01)$ terhadap pertambahan bobot badan kelinci.

Perbedaan antar perlakuan maka dilakukan dengan uji Tukey.Dari hasil uji Tukey didapat rataan bobot badan pada perlakuan P0 (kulit ubi fermentasi $0 \%+$ rumput lapangan) memberikan nilai rataan yang berbeda terhadap perlakuan P1, P2, dan P3.Perlakuan P1 memberikan nilai rataan yang berbeda nyataa terhadaap perlakuan P2 dan P3.Perlakuan P2 memberikan nilai rataan yang berbeda nyata terhadap perlakuan P3 Pertambahan bobot badan kelinci cenderung menurun dan lebih rendah dari pada perlakuan P0 (kulit ubi fermentasi 0\% + rumput lapangan).

Hal ini berbanding lurus dengan tabel konsumsi. Pada perlakuan P0 tingkat konsumsi lebih besar dibandingkan dengan perlakuan lain dan menghasilkan pertambahan bobot badan yang lebih besar juga dibandingkan perlakuan lain. Thalib et al., (2001), menyatakan bahwa pertambahan bobot tubuh ternak sangat dipengaruhi oleh kualitas dan kuantitas pakan, maksudnyapenilaian pertambahan bobot tubuh ternak sebanding dengan ransum yangdikonsumsi.

Tabel 3 diatas menunjukkan bahwa rataan umum pertambahan bobot badan adalah sebesar 25,8 gram/ekor/hari. Angka tersebut lebih rendah daripada angka rata-rata pertambahan bobot badan yang diharapkan pada pemeliharaan kelinci menurutReksohadiprojo (1984), untuk periode 8-14 minggu yaitu 33,2 gram/ekor/hari. Penurunan pertumbuhan bobot badan dipengaruhi oleh penurunan tingkat konsumsi.Ensminger (1991), mengatakan bobot badan dapat menentukan penampilan ternak tersebut serta keturunannya, bobot badan dapat bervariasi karena dipengaruhi oleh bangsa, umur, genetik, pakan, suhu, lingkungan dan sebagainya.

\section{Konversi Pakan}

Konversi pakan dihitung dengan cara membandingkan banyak jumlah pakan yang dikonsumsi, dengan pertambahan bobot badan yang dicapai setiap minggunya berdasarkan pengukuran dikandang dan nilai yang diperoleh. Tabel 3 menunjukkan rata-rata konversi pakan kelinci dari masing-masing perlakuan selama penelitian adalah $\mathrm{P} 0=3,69, \mathrm{P} 1=3,74$, $\mathrm{P} 2=3,86$ dan $\mathrm{P} 3=4,03$. Konversi pakan kelinci terendah secara kuantitatif dicapai pada perlakuan P0 (kulit ubi fermentasi 0\% + rumput lapangan) dan P1 (kulit ubi fermentasi 10\% + rumput lapangan)serta konversi pakan yang tertinggidicapai pada perlakuan P3 (kulit ubi 
fermentasi 30\% + rumput lapangan). Berdasarkan hasil analisis ragam dapat diketahui bahwa penggunaan kulit ubi kayu fermentasi dalam pakan memberikan pengaruh berbeda sangat nyata $(\mathrm{P}<0,01)$ terhadap pertambahan konversi pakan kelinci.

Pada Tabel 3 dapat dilihat bahwa penambahan kulit ubi fermentasi dalam ransum memberikan pengaruh yang tidak berbeda nyata terhadap konversi ransum sampai pada level 10\% yaitu perlakuan P1dan memberikan pengaruh yang berbeda nyata sampai level 30\% yaitu perlakuan P2 dan P3.Perlakuan P1 memberikan pengaruh yang tidak nyata terhadap P2 dan memberikan pengaruh berbeda nyata terhadap perlakuan P3.Perlakuan P2 memberikan pengaruh yang nyata berbeda terhadap perlakuan P3.Perbedaan nilai konversi ransum kelinci yang diberi perlakuan P3 dibandingkan dengan perlakuan lainnya dapat disebabkan antara lain oleh tingkat palatabilitas kelinci untuk mengomsumsi ransum yang akan menghasilkan pertambahan bobot badan. Campbell dan Lasley (1985), mengatakan bahwa faktor-faktor yang mempengaruhi konversi ransum adalah genetik, umur, berat badan, tingkat konsumsi makanan, pertambahan bobot badan perhari, palatabilitas dan hormon.

\section{KESIMPULAN}

Penambahan kulit ubi fermentasi Rhizopus sp, Saccharomyces sp dan Lactobacillus sp dalam ransum cenderung mempengaruhi penurunan tingkat konsumsi, penurunan pertambahan bobot badan serta menurunkan nilai efisiensi pakan kelinci New Zealand White yang diteliti.

\section{DAFTARPUSTAKA}

Campbell, J.R. dan J.F. Lasley. 1985. The Science of Animal that Serve Humanity. $2^{\text {nd }}$ Ed., Tata McGraw-Hill Publishing Co. Ltd., New Delhi.

Devendra, C. 1987. Expanding the Utilization of Agro-industrial by Product and non Conventional Feed Resource In Asia. Symposium on Animal Feed Resources, Asian Productivity Organization, 24-29 August 1987, Tokyo, Japan.

Ensminger, M. E. 1991. Feeds and Nutrition.Second Edition. The Ensminger Publising Company. USA.

Hanafiah, K.A. 2003. Rancangan Percobaan. Fakultas Pertanian, Universitas Sriwijaya.Palembang.

Herman, R. 2000. Produksi Kelinci dan Marmut. Edisi Tiga. Fakultas Peternakan. Institut Pertanian Bogor, Bogor.

Masanto, R., dan Agus, A. 2010. Beternak Kelinci Potong. Penebar Swadaya. Jakarta.

National Reseach Council. 1977. Nutrient Requirement of Rabbit. National Academic of Science, Washington.

Nurhayani, H., Nuryati, J., I Nyoman, P. 2000. Peningkatan Kandungan Protein Kulit Umbi Ubi Kayu Melalui Proses Fermentasi .Departemen Biologi 
Fak. MIPA ITB.Bandung.http://journal.fmipa.itb.ac.id/jms/article/viewFile/63/57JM S Vol. 6 No. 1, hal. 1 - 12 April 2001

Piliang WG. 2000. Fisiologi Nutrisi. Volume I. Bogor: Institut Pertanian Bogor.

Suyatno. 2011. Pengolahan Fisik Kulit Ubi Kayu Sebagai Pakan Ternak. http://suyat-reproter.blogspot.com/2011/05/pengolahan-fisik-kulit-ubi-

kayu-sebagai.html

Thalib, A., B. Haryanto, H. Hanid, D. Suherman \& Mulyani. 2001. Pengaruh kombinasi defaunatior dan probiotik terhadap ekosistem rumen dan performanternak domba. J. IlmuTernak dan Veteriner, 6 (2):83-88. 